\title{
PENGARUH DETERMINASI PENYALURAN KREDIT TERHADAP PROFITABILITAS BANK UMUM TERDAFTAR DI BURSA EFEK INDONESIA (BEI)
}

\author{
${ }^{1}$ Jemmy Firdaus, ${ }^{2}$ Fakhry Zamzam, ${ }^{3}$ Harsi Romli \\ ${ }^{1}$ Mahasiswa Program Magister Universitas IGM, Email: jefier.13@gmail.com \\ ${ }^{2}$ Program Magister Universitas IGM, Email: fakhry@uigm.ac.id \\ ${ }^{3}$ Program Magister Universitas IGM, Email: harsi@uigm.ac.id
}

\begin{abstract}
This research aims to determine the influence of credit distribution determinations of Spread of Interest Rate (SIR), Loan to Deposit Ratio (LDR) and Non Perfoming Loan (NPL) against the profitability of commercial banks. The focus of research is on the banking industry listed on the Indonesia Stock Exchange (IDX). The population used in this research is a public bank listed on the Indonesia Stock Exchange in 2010-2018. This study uses multiple regression analysis methods with data processing techniques using 8 eviews. The test results proved that: 1) The increase in SIR has no effect on the profitability of the national commercial Bank located in IDX period 2010-2018. ; 2) The increase of LDR negatively affects the profitability of the national commercial Bank located in IDX period 2010-2018; 3) The NPL increase affects the increase in profitability of the national commercial Bank located in the IDX period 2010-2018.
\end{abstract}

Keywords: Spread of Interest Rate, Loan to Deposit Ratio, Non Perfoming Loan, Profitabilitas

\begin{abstract}
Abstrak
Penelitian ini bertujuan untuk mengetahui pengaruh determinasi penyaluran kredit berupa Spread of Interest Rate (SIR), Loan to Deposit Ratio (LDR) dan Non Perfoming Loan (NPL) terhadap profitabilitas bank umum. Adapun focus penelitian adalah pada industri perbankan yang terdaftar pada Bursa Efek Indonesia (BEI). Populasi yang digunakan dalam penelitian ini adalah bank umum yang terdaftar di Bursa Efek Indonesia tahun 2010-2018. Penelitian ini menggunakan metode analisis regresi berganda (multiple regression analisys) dengan teknik pengolahan data menggunakan eviews 8. Hasil pengujian membuktikan bahwa: 1) Peningkatan SIR tidak berpengaruh terhadap profitabilitas pada Bank Umum Nasional yang terdapat di BEI periode 2010-2018. ; 2) Kenaikan LDR berpengaruh negatif terhadap profitabilitas pada Bank Umum Nasional yang terdapat di BEI periode 2010-2018; 3) Kenaikan NPL memengaruhi terhadap peningkatan profitabilitas pada Bank Umum Nasional yang terdapat di BEI periode 2010-2018. ; 4) Kenaikan SIR, LDR dan NPL secara bersama-sama berpengaruh terhadap peningkatan profitabilitas pada Bank Umum Nasional yang terdapat di BEI periode 2010-2018.
\end{abstract}

Kata Kunci: Spread of Interest Rate, Loan to Deposit Ratio, Non Perfoming Loan, Profitabilitas 
138 | Jemmy Firdaus, Luis Marnisah, Fakhry Zamzam, Pengaruh Determinasi Penyaluran........

\section{DASAR PEMIKIRAN}

\section{Latar Belakang.}

Perkembangan dan pembangunan ekonomi disuatu negara sangat bergantung pada perkembangan dinamis dan kontribusi nyata dari sektor perbankan. Bank umum pemerintah (Commercial Bank) memiliki peranan yang sangat penting dalam menggerakkan roda perekonomian nasional, karena lebih dari 95\% Dana Pihak Ketiga (DPK) perbankan nasional yang meliputi Bank umum pemerintah (Commercial Bank), Bank Syariah (Sharia Bank), dan Bank Perkreditan Rakyat (Rural Bank) berada di Bank umum pemerintah. DPK ini yang selanjutnya digunakan untuk mendorong pertumbuhan ekonomi melalui penyaluran kredit. Penyaluran kredit dapat membantu masyarakat dalam melakukan berbagai kegiatan ekonomi yang berkontribusi terhadap pembangunan perekonomian masyarakat. Meskipun penyaluran kredit memegang peranan penting bagi pertumbuhan ekonomi suatu negara, namun kredit yang disalurkan oleh perbankan belum optimal, hal ini dapat dilihat dari data Bank Indonesia pada 17-18 Januari 2018 memutuskan untuk mempertahankan BI 7-day Reverse Repo Rate tetap sebesar 4,25\%, dengan suku bunga Deposit Facility tetap sebesar 3,50\% dan Lending Facility tetap sebesar 5,00\%, berlaku efektif sejak 19 Januari 2018. Kebijakan tersebut konsisten dengan terjaganya stabilitas makroekonomi dan sistem keuangan serta turut mendukung pemulihan ekonomi domestik.

Di samping keputusan suku bunga tersebut, RDG juga memutuskan untuk mempercepat implementasi Giro Wajib Minimum (GWM) Rata-rata sebagai kelanjutan dari reformasi kerangka operasional kebijakan moneter dalam rangka meningkatkan efektivitas transmisi kebijakan moneter, mendukung fleksibilitas manajemen likuiditas perbankan, dan sekaligus mempercepat pendalaman pasar keuangan. Dari total GWM Rupiah bank umum pemerintah konvensional sebesar 6,5\% dari Dana Pihak Ketiga (DPK), porsi GWM Rata-rata diperlonggar dari 1,5\% menjadi $2 \%$ dari DPK. Sementara, dari total GWM Valas bank umum pemerintah konvensional sebesar $8 \%$ dari DPK, porsi GWM Rata-rata mulai diberlakukan sebesar 2\% dari DPK. Untuk bank umum pemerintah syariah dan Unit Usaha Syariah (UUS), dari total GWM Rupiah sebesar 5\% dari DPK, porsi GWM Rata-rata mulai diberlakukan sebesar 2\% dari DPK. 
Dalam rangka mendorong fungsi intermediasi dan pengelolaan likuiditas perbankan, RDG memutuskan untuk menyempurnakan kebijakan makroprudensial melalui pemberlakuan dua ketentuan. Pertama, mengubah ketentuan Loan to Funding Ratio (LFR) bagi Bank umum pemerintah Konvensional (BUK) dan ketentuan Financing to Deposit Ratio (FDR) bagi Bank umum pemerintah Syariah (BUS) dan Unit Usaha Syariah (UUS) menjadi Rasio Intermediasi Makroprudensial (RIM) dengan target kisaran 80-92\% serta memperluas komponen kredit/pembiayaan yang memasukkan Surat-Surat Berharga (SSB) yang dibeli oleh bank dan memperluas komponen simpanan dengan memasukkan SSB yang diterbitkan oleh BUS dan UUS. Kedua, mengubah ketentuan GWM sekunder bagi BUK menjadi Penyangga Likuiditas Makroprudensial (PLM) dan memberlakukan PLM bagi BUS dengan besaran $4 \%$ dari DPK, dengan disertai fleksibilitas sebesar 2\% dari DPK dapat direpokan kepada Bank Indonesia dalam kondisi tertentu untuk memenuhi kebutuhan likuiditas bank. Kedua instrumen makroprudensial tersebut bersifat countercyclical yang dapat disesuaikan sejalan dengan siklus ekonomi dan keuangan.

Stabilitas sistem keuangan tetap terjaga di tengah intermediasi perbankan yang belum kuat. Terjaganya stabilitas sistem keuangan tercermin pada rasio kecukupan modal (Capital Adequacy Ratio/CAR) perbankan yang cukup tinggi pada level 23,2\% dan rasio likuiditas (AL/DPK) pada level 22,3\% pada November 2017. Sementara itu, sejalan dengan upaya penguatan manajemen risiko kredit perbankan, rasio kredit bermasalah (Non Performing Loan/NPL) berada pada level 2,89\% (gross) atau 1,25\% (net), lebih rendah dibandingkan Oktober 2017 yaitu sebesar 2,96\% (gross) atau 1,29\% (net). Transmisi pelonggaran kebijakan moneter melalui jalur suku bunga terus berlangsung, tercermin dari berlanjutnya penurunan suku bunga deposito dan suku bunga kredit, meski belum dalam besaran yang diharapkan. Transmisi melalui jalur kredit juga masih belum optimal, tercermin pada pertumbuhan kredit yang masih terbatas sejalan dengan permintaan kredit yang belum tinggi dan perilaku bank yang masih selektif dalam memberikan kredit baru. Pertumbuhan kredit November 2017 tercatat sebesar 7,5\% (yoy), lebih rendah dibandingkan periode yang sama tahun sebelumnya yaitu sebesar 8,5\% (yoy). Di tengah pertumbuhan kredit perbankan yang terbatas, pembiayaan ekonomi melalui pasar keuangan, seperti penerbitan saham, 
140 | Jemmy Firdaus, Luis Marnisah, Fakhry Zamzam, Pengaruh Determinasi Penyaluran........

obligasi, dan medium term notes (MTN), terus tumbuh tinggi hingga mencapai 29,7\% (yoy) pada November 2017. Sementara itu, pertumbuhan DPK pada November 2017 tercatat 9,8\% (yoy), menurun dibandingkan bulan sebelumnya 11,0\% (yoy). Dengan perkembangan tersebut, untuk keseluruhan 2017, DPK dan kredit diperkirakan tumbuh masing-masing sekitar 9,0\% (yoy) dan 8,0\% (yoy). Sejalan dengan perkiraan perbaikan ekonomi dan penerapan kebijakan makroprudensial terkait intermediasi dan pengelolaan likuiditas, serta progres program konsolidasi korporasi dan perbankan yang ditempuh, Bank Indonesia memperkirakan pertumbuhan DPK dan kredit akan lebih baik pada 2018, masing-masing dalam kisaran 9,0-11,0\% (yoy) dan 10,0-12,0\% (yoy).

\section{Rumusan Masalah}

a. Bagaimanakah pengaruh penyaluran kredit terhadap profitabilitas?

b. Bagaimanakah keadaan penyaluran kredit bank umum pemerintah saat ini?

c. Apakah spread of interes rate, loan to deposit ration dan non perfoming loan berpengaruh terhadap profitabilitas?

\section{Kajian Pustaka}

\subsection{Spread of Interest Rate}

Istilah ini sering disamakan penggunaannya dengan margin meskipun kedua istilah ini sebenarnya memiliki pengertian yang lebih spesifik. Spread dalam pengertian umum adalah selisih antara biaya dana (Borrowing Rate) dengan tingkat bunga kredit (Lending Rate) atau selisih antara Bidding Rate dan Offering Rate yang sering digunakan dalam transaksi pasar uang. Sementara istilah margin sering dikaitkan dengan perbedaan tingkat risiko antara kedua jenis suatu investasi atau surat berharga.

$$
\text { Spread }=\frac{\text { Penerimaan Bunga }}{\text { Earning Assets }}-\frac{\text { Pengeuaran Bunga }}{\text { Dana yang Berbeban Bunga }}
$$

Spread of interest rate merupakan selisih penerimaan bunga dengan pengeluaran bunga. Semakin tinggi nilai spread mengindikasikan semakin tinggi profitabilitas sebaliknya, semakin rendah spread maka semakin rendah pula profitabilitas (Tasman et, 2015). 


\subsection{Loan to Deposit Ratio}

Pengertian Loan to Deposit Ratio (LDR) menurut Martono (2002:82) menyatakan bahwa:

"Loan to Deposit Ratio adalah rasio untuk mengetahui kemampuan bank dalam membayar kembali kewajiban kepada nasabah yang telah menanamkan dananya dengan kredit-kredit yang telah diberikan kepada para debiturnya."

$$
L D R=\frac{\text { Total Loan }}{\text { Total Deposit }+ \text { Equity }}
$$

Dari penjelasan diatas dapat disimpulkan bahwa Loan To Deposit Ratio (LDR) merupakan kemampuan Bank dalam membayar kembali dana penarikan yang telah dilakukan oleh deposan dengan mengandalkan kredit untuk mengetahui tingkat likuidasinya.

\subsection{Non Performing Loan}

Pengertian kredit bermasalah adalah suatu keadaan dimana nasabah sudah tidak sanggup membayar sebagian atau seluruh kewajibannya kepada bank seperti yang telah dijanjikannya

$$
N P L=\frac{\text { Kredit Bermasalah }}{\text { Total Kredit }} \times 100 \%
$$

Jadi, semakin tinggi kredit bermasalah maka semakin rendah profitabilitas bank, sebaliknya semakin rendah kredit bermasalah maka semakin tinggi profitabilitas bank. Oleh sebab itu, kredit bermasalah mengindikasikan berpengaruh negatif terhadap profitabilitas dengan perjanjian yang telah ditandatangani oleh bank dan nasabah.

\subsection{Profitabilitas}

Menurut Kasmir (2005:304) profitabilitas atau kemampuan memperoleh laba adalah suatu ukuran dalam persentase yang digunakan untuk menilai sejauh mana perusahaan mampu menghasilkan laba pada tingkat pendapatan yang diterima. Angka profitabilitas dinyatakan antara lain dalam angka laba sebelum pajak, laba investasi, pendapatan per saham, dan laba perusahaan. Nilai profitabilitas menjadi ukuran bagi kesehatan perusahaan dan menunjukkan efisiensi perusahaan.

Salah satu indikator yang digunakan untuk melihat kinerja keuangan dari sisi profitabilitas adalah 
Return on Assets (ROA). ROA $=\frac{\text { Laba Sebelum Pajak }}{\text { Total Asset }} \times 100 \%$

Semakin besar ROA suatu bank maka semakin besar pula tingkat keuntungan yang dicapai bank tersebut, dan semakin baik pula posisi bank tersebut dari segi penggunaan aset.

\subsection{Rasio Profitabilitas}

Menurut Kasmir (2014:115) definisi rasio profitabilitas merupakan rasio untuk menilai kemampuan perusahaan dalam mencari keuntungan. Rasio ini juga memberikan ukuran tingkat efektivitas manajemen suatu perusahaan.

\subsection{Penelitian Terdahulu}

Hasil penelitian (Zulfa Majidi, 2016) menyatakan bahwa CAR, NPL, dan LDR tidak berpengaruh nyata terhadap profitabilitas pada perusahaan perbankan yang listing di BEI (2010-2018). Pandu Mahardian (2008) melakukan penelitian yang bertujuan untuk menganalisis pengaruh Capital Adequacy Ratio (CAR), BOPO, Non Performing Loan (NPL), Net Interest Margin (NIM), dan Loan to Deposit Ratio (LDR) terhadap Return On Asset (ROA). Pengujian penelitian dilakukan menggunakan regresi linier berganda. Hasil penelitiannya menyatakan bahwa CAR berpengaruh positif signifikan terhadap ROA, BOPO berpengaruh negatif signifikan terhadap ROA, NIM berpengaruh positif signifikan terhadap ROA, dan LDR berpengaruh positif signifikan terhadap ROA. Sedangkan NPL tidak memiliki pengaruh terhadap ROA.

\subsection{Kerangka Pemikiran Teoritis}

Berdasarkan rumusan masalah dan telaah pustaka di atas, guna mempermudah dalam melakukan penelitian ini, maka diperlukan suatu kerangka pemikiran yang jelas, maka bagian alur kerangka sebagai berikut: 


\section{Gambar 2.1 Kerangka Pemikiran}

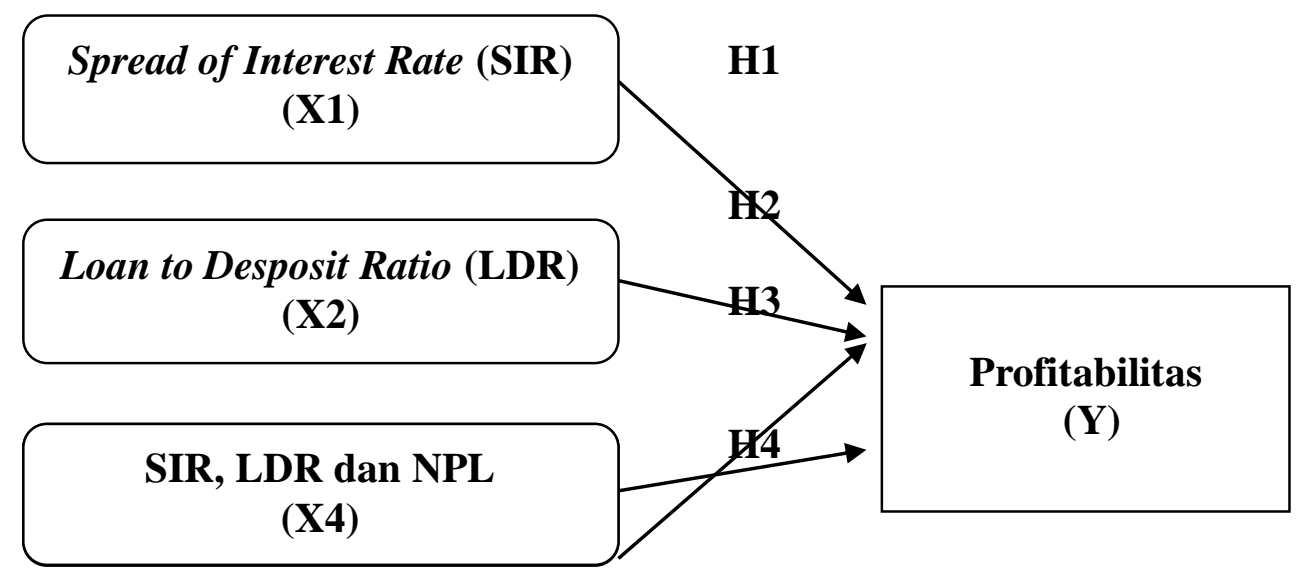

\section{Metodologi Penelitian}

\subsection{Metode Penelitian}

Penelitian ini menggunakan metode kuantitatif yang menggambarkan keadaan sebenarnya dari obyek penelitian. Kegiatan ini dilakukan dengan mempelajari laporan keuangan beberapa bank umum pemerintah yang terdaftar di BEI. Studi ini dimaksudkan untuk memperoleh data bank yang berkaitan dengan pengukuran Spread of interest rate, loan to deposit ratio, non performing loan dan profitabilitas bank yang dalam penelitian ini Return of Assets (ROA).

\subsection{Populasi, Sampel}

Populasi yang digunakan dalam penelitian ini adalah Bank Swasta Nasional di Indonesia yang terdiri dari 57 bank swasta nasional. Sampel dalam penelitian ini diperoleh dengan metode purposive sampling yaitu sampel yang diambil berdasarkan kriteria - kriteria yang digunakan oleh peneliti. Sampel yang diambil yaitu sebanyak Empat Bank umum pemerintah Pemerintah di Indonesia yang terdaftar di Bursa Efek Indonesia (BEI) tahun 2010 - 2018 yaitu : BNI, Bank Mandiri, BRI dan Bank BTN.

\subsection{Teknik Analisis Data}

Penelitian ini menggunakan model analisis regresi berganda untuk menganalisis pengaruh SIR, LDR dan NPL terhadap ROA, dengan model dasar sebagai berikut: $\mathrm{Y}=$ $b_{0}+b_{1} X_{1}+b_{2} X_{2}+b_{3} X_{3}+e t$ 
144 | Jemmy Firdaus, Luis Marnisah, Fakhry Zamzam, Pengaruh Determinasi Penyaluran........

Dimana :

$$
\begin{array}{ll}
\mathrm{Y} & =\text { ROA } \\
\mathrm{a} & =\text { konstanta } \\
\mathrm{X}_{1} & =\text { SIR } \\
\mathrm{X}_{2} & =\mathrm{LDR} \\
\mathrm{X}_{3} & =\text { NPL } \\
\mathrm{b}_{1}-\mathrm{b}_{3} & =\text { Koefisien Regresi } \\
\mathrm{e} & =\text { standar error }
\end{array}
$$

\subsection{Uji Statistik}

\subsubsection{Uji Koefesiensi Determinasi $\left(\mathbf{R}^{2}\right)$}

Koefisien determinasi $\left(\mathrm{R}^{2}\right)$ pada intinya mengukur seberapa jauh kemampuan model dalam menerangkan variasi variabel dependen. Nilai yang mendekati satu berarti variabel-variabel independen memberikan hampir semua informasi yang dibutuhkan untuk memprediksi variasi variabel dependen (Imam Ghozali, 2013: 97).

\subsubsection{Uji T}

Menurut Imam Ghozali (2013:98) uji statistik t pada dasarnya menunjukkan seberapa jauh pengaruh satu variabel independen secara individual 46 dalam menerangkan variabel dependen. Pengujian dilakukan dengan menggunakan signifikan level 0,05 $(\alpha=5 \%)$. Penerimaan atau penolakan hipotesis dilakukan dengan kriteria:

1. Jika nilai signifikan >0,05 maka hipotesis ditolak (koefisien regresi tidak signifikan). Ini berarti secara parsial variabel independen tidak mempunyai pengaruh secara signifikan terhadap variabel dependen.

2. Jika nilai signifikan $\leq 0,05$ maka hipotesis diterima (koefisien regresi signifikan). Ini berarti secara parsial variabel independen tersebut mempunyai pengaruh yang signifikan terhadap variabel dependen. 


\subsubsection{Uji F}

Menurut Imam Ghozali (2013:98) Uji statistik F pada dasarnya menunjukkan apakah semua variabel independen yang dimasukkan dalam model mempunyai pengaruh secara bersama-sama terhadap variabel terikat.

\section{Hasil Dan Pembahasan}

\subsection{Pengujian Asumsi Klasik}

Uji asumsi klasik merupakan persyaratan statistik yang harus dipenuhi pada analisis regresi linear berganda yang berbasis ordinary least square (OLS). Jadi analisis regresi yang tidak berdasarkan OLS tidak memerlukan persyaratan asumsi klasik, misalnya regresi logistik atau regresi ordinal. Persyaratan asumsi klasik pada penelitian ini meliputi uji normalitas dan uji heteroskedastisitas.

\subsection{Hasil Pengujian Normalitas}

Pengujian normalitas data adalah pengujian tentang kenormalan distribusi data. Pengujian normalitas dilakukan dengan maksud untuk melihat normal tidaknya data yang dianalisis. Normalitas dapat dideteksi dengan menggunakan uji Jarque-Berra (uji JB). Uji JB merupakan uji normalitas berdasarkan pada koefisien keruncingan (kurtosis) dan koefisien kemiringan (skewness). Dalam uji JB normalitas dapat dilihat dari besaran nilai probability JB, jika nilai probability JB > 0,05 maka data berdistribusi normal, sebaliknya jika nilai probability $<0,05$ maka data berdistribusi tidak normal. Adapun hasil pengujian normalitas pada PT Indofood Sukses Makmur Tbk dapat dilihat dalam tabel sebagai berikut: 
146 | Jemmy Firdaus, Luis Marnisah, Fakhry Zamzam, Pengaruh Determinasi Penyaluran........

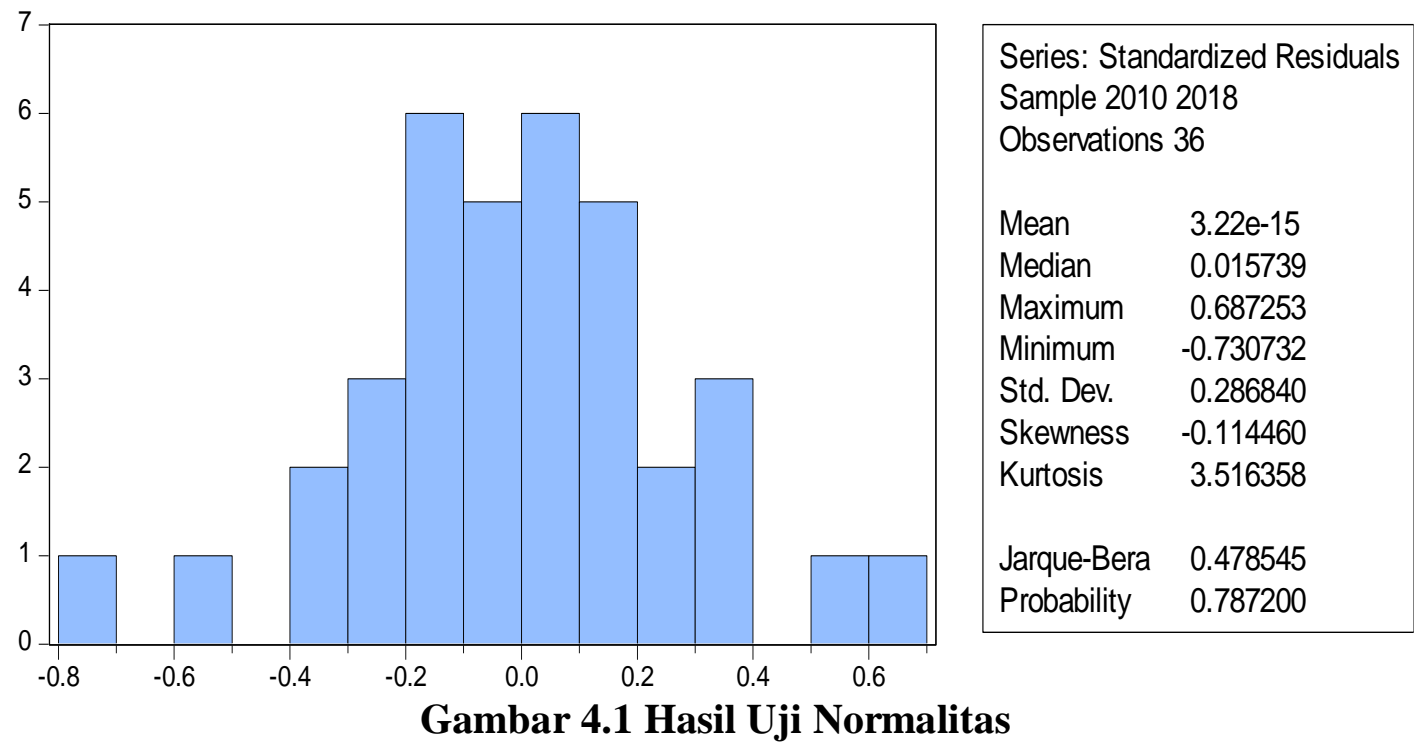

Berdasarkan Gambar 4.1 diketahui bahwa nilai probability sebesar 0.787200 . Karena nilai prob. $0.787200>0,05$ maka data berdistribusi normal. Sehingga dapat disimpulkan bahwa asumsi berdistribusi normal dalam model terpenuhi.

\subsection{Hasil Pengujian Heteroskedastisitas}

Uji heteroskedastisitas merupakan bagian dari uji asumsi klasik dalam model regresi. Dimana salah satu persyaratan yang harus dipenuhi dalam model regresi yang baik adalah tidak terjadi heteroskedastisitas. Uji heteroskedastisitas bertujuan untuk menguji terjadinya perbedaan variance dari nilai residual pada satu periode pengamatan ke periode pengamatan yang lainnya.

Tabel 4.2

Hasil Uji Heteroskedastisitas

\begin{tabular}{|c|c|c|c|c|}
\hline \multicolumn{4}{|c|}{\begin{tabular}{|l|l} 
Dependent Variable: ROA & \\
\end{tabular}} & \\
\hline \multicolumn{4}{|c|}{ Method: Panel EGLS (Cross-section weights) } & \\
\hline \multicolumn{5}{|c|}{ Date: 01/29/20 Time: $20: 09$} \\
\hline \multicolumn{5}{|c|}{ Sample: 20102018} \\
\hline \multicolumn{5}{|c|}{ Periods included: 9} \\
\hline \multicolumn{4}{|c|}{\begin{tabular}{l|l} 
Cross-sections included: 4 & \\
\end{tabular}} & \\
\hline \multirow{2}{*}{\multicolumn{5}{|c|}{ Total panel (balanced) observations: 36}} \\
\hline & \multicolumn{3}{|c|}{ Linear estimation after one-step weighting matrix } & \\
\hline Variable & Coefficient & Std. Error & t-Statistic & Prob. \\
\hline
\end{tabular}




\begin{tabular}{|c|c|c|c|c|}
\hline \hline & & & & \\
\hline C & 13.44294 & 4.913356 & 2.736000 & 0.0101 \\
\hline SIR & 0.131203 & 0.085491 & 1.534705 & 0.1347 \\
\hline LDR & -0.145146 & 0.057758 & -2.512997 & 0.0172 \\
\hline NPL & 0.481446 & 0.141921 & 3.392353 & 0.0019 \\
\hline & Weighted Statistics & & \\
\hline \hline R-squared & 0.462003 & Mean dependent var & 3.060564 \\
\hline Adjusted R-squared & 0.411566 & S.D. dependent var & 0.872240 \\
\hline S.E. of regression & 0.298366 & Sum squared resid & 2.848714 \\
\hline F-statistic & 9.159961 & Durbin-Watson stat & 1.401839 \\
\hline Prob(F-statistic) & 0.000160 & \multicolumn{3}{|l}{} \\
\hline \hline & Unweighted Statistics & & \\
\hline & 0.443619 & Mean dependent var & 2.838889 \\
\hline \hline R-squared & 2.907398 & Durbin-Watson stat & 1.313094 \\
\hline Sum squared resid & \multicolumn{5}{|l}{} \\
\hline \hline
\end{tabular}

Berdasarkan uji glejser Heteroskedastisitas dengan nilai dari probabilitas chisquare sebesar 0.0843 lebih besar dari taraf signifikan $(\alpha=5 \%)$ yang berarti tidak signifikan, maka menerima $\mathrm{H} 0$ atau menolak Ha yang berarti bahwa tidak ada masalah heterokedastisitas.

\subsection{Hasil Pengujian Hipotesis}

Dalam penelitian ini uji hipotesis menggunakan analisis regresi linier berganda dengan tools analisis eviews. Hasil uji regresi linier berganda dalam penelitian menggunakan tools ana;isis eviews disajikan selengkapnya dalam tabel sebagai berikut:

Tabel 4.3.

Hasil Analisis Regresi

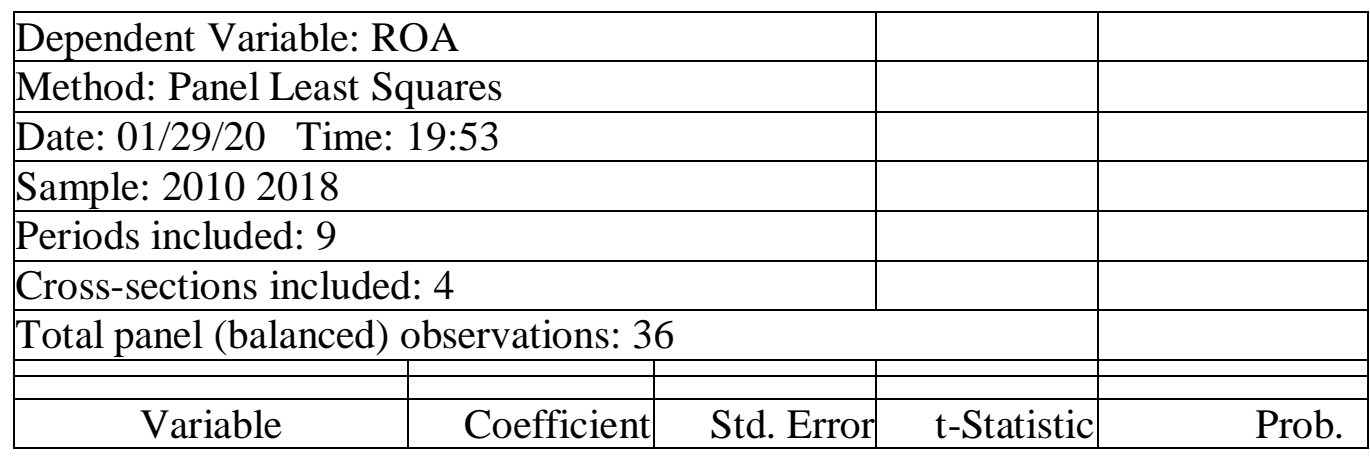




\begin{tabular}{|c|r|r|r|r|}
\hline & & & & \\
\hline C & 14.09877 & 4.929300 & 2.860197 & 0.0074 \\
\hline LIR & 0.129392 & 0.101115 & 1.279650 & 0.2099 \\
\hline LDR & -0.152805 & 0.058022 & -2.633575 & 0.0129 \\
\hline \hline R-squared & 0.445456 & 0.133425 & 3.338634 & 0.0021 \\
\hline Adjusted R-squared & 0.448918 & Mean dependent var & 2.838889 \\
\hline S.E. of regression & 0.397254 & S.D. dependent var & 0.386396 \\
\hline Sum squared resid & 0.299985 & Akaike info criterion & 0.534269 \\
\hline Log likelihood & 2.879708 & Schwarz criterion & 0.710216 \\
\hline F-statistic & -5.616849 & Hannan-Quinn criter. & 0.595679 \\
\hline Prob(F-statistic) & 8.689203 & Durbin-Watson stat & 1.313051 \\
\hline \hline
\end{tabular}

Dari tabel 4.3 di atas digunakan untuk pegujian hipotesis penelitian dengan hasil sebagai berikut;

\section{Hipotesis-1}

Ho : Tidak Terdapat pengaruh Spread of Interest Rate terhadap profitabilitas pada Bank umum pemerintah Nasional Terdaftar di BEI Periode 2010-2018.

H1 : Terdapat pengaruh Spread of Interest Rate terhadap profitabilitas pada Bank umum pemerintah Nasional Terdaftar di BEI Periode 2010-2018.

Berdasarkan hasil pengolahan data menggunakan tools analisis di atas, bahwa nilai $\mathrm{t}$ statistic $1.279<\mathrm{t}$ tabel 2,021 dan signifikansi 0.2099 lebih besar dibandingkan dengan derajat signifikansi sebesar 0.05. sehingga Spread of Interest Rate tidak berpengaruh terhadap ROA. Dengan demikian Ho diterima dan H1 ditolak, maka hipotesis 1 menyimpulkan bahwa Spread of Interest Rate tidak berpengaruh terhadap ROA

\section{Hipotesis 2}

Ho : Tidak terdapat Pengaruh Loan to Desposit Ratio terhadap profitabilitas pada Bank umum pemerintah Nasional Terdaftar di BEI Periode 2010-2018.

H1 : Terdapat Pengaruh Loan to Desposit Ratio terhadap profitabilitas pada Bank umum pemerintah Nasional Terdaftar di BEI Periode 2010-2018.

Nilai probabilitas variabel Loan to Desposit Ratio yaitu 0.0129 lebih kecil dibandingkan nilai derajat signifikansi 0.05 dan t statistic -2.633>t tabel 2,021 Angka ini menjelaskan bahwa Loan to Desposit Ratio berpengaruh positif dan signifikan 
terhadap ROA. Dengan demikian Ho ditolak dan H1 dapat diterima, maka hipotesis 2 menyimpulkan terdapat pengaruh Loan to Desposit Ratio negatif dan signifikan terhadap ROA.

\section{Hipotesis 3}

Ho : Tidak terdapat Pengaruh Non Performing Loan terhadap profitabilitas pada Bank umum pemerintah Nasional Terdaftar di BEI Periode 2010-2018.

H1 : Terdapat Pengaruh Non Performing Loan terhadap profitabilitas pada Bank umum pemerintah Nasional Terdaftar di BEI Periode 2010-2018.

Nilai probabilitas t statistic variabel Non Performing Loan sebesar $3.338>\mathrm{t}$ tabel 2,021, dan signifikansi 0,0021 lebih kecil dibandingkan nilai derajat signifikansi 0.05 , berarti bahwa Non Performing Loan berpengaruh positif dan signifikan terhadap ROA. Dengan demikian Ho ditolak dan h1 diterima, maka hasil hipotesis 3 menyimpulkan bahwa Non Performing Loan berpengaruh positif dan signifikan terhadap ROA.

\section{Hipotesis 4}

Ho : Tidak Terdapat Pengaruh Spread of Interest Rate, Loan to Desposit Ratio dan Non Performing Loan terhadap profitabilitas pada Bank umum pemerintah Nasional Terdaftar di BEI Periode 2010-2018.

H1 : Terdapat Pengaruh Spread of Interest Rate, Loan to Desposit Ratio dan Non Performing Loan terhadap profitabilitas pada Bank umum pemerintah Nasional Terdaftar di BEI Periode 2010-2018.

Berdasarkan Tabel 4.3 bahwa nilai F statictic $8.689>\mathrm{F}$ tabel 4.124 variabel SIR, LDR dan NPL dan signifikansi sebesar 0.000232 atau lebih kecil dibandingkan nilai taraf derajat signifikansi sebesar 0.05. Hal ini menjelaskan bahwa SIR, LDR dan NPL secara bersama-sama berpengaruh signifikan terhadap ROA. Dengan demikian Ho ditolak dan H1 diterima, maka hipotesis 4 menyimpulkan bahwa SIR, LDR dan NPL secara bersama-sama berpengaruh signifikan terhadap ROA. 
150 | Jemmy Firdaus, Luis Marnisah, Fakhry Zamzam, Pengaruh Determinasi Penyaluran........

\subsection{Penyaluran Kredit Pada Bank Milik Pemerintah}

Determinan kredit juga ditentukan oleh beberapa produk yaitu diantaranya; KUR (Kredit Usaha Rakyat), Deposito, Investasi, Kartu Kredit dan Profesi. Profitabilitas juga ditentukan adanya tujuan yang jelas dalam mengelola uang nasabah, profitabilitas atau likuiditas dari bank tersebut dapat diketahui dengan adanya kemampuan membayar uang nasabah (load to deposit ratio), sehingga image yang ditampilkan begitu baik dan sehat. Tentunya menjadi tujuan profitabilitas juga untuk memberikan rasa nyaman dan keuntungan kepada nasabah melalui varian-varian produk.

Tabel 4.4. Determinan Kredit dan Profitabilitas Nasabah (BNI)

\begin{tabular}{|l|c|c|c|c|}
\hline \multicolumn{1}{|c|}{ Jenis Produk } & 6 Bulan & 12 Bulan & 24 Bulan & 36 Bulan \\
\hline KUR & $7 \%$ & $7 \%$ & $7 \%$ & $7 \%$ \\
\hline Deposito Rupiah & $5.7 \%$ & $6.4 \%$ & $6 \%$ & $5.7 \%$ \\
\hline Deposito Dollar & $2 \%$ & $2.2 \%$ & $2.1 \%$ & $1.4 \%$ \\
\hline Kredit Retail & $11.5 \%$ & $11.5 \%$ & $11.5 \%$ & $11.5 \%$ \\
\hline Kartu Kredit & $2.75 \%$ & $2.75 \%$ & $2.75 \%$ & $2.75 \%$ \\
\hline Kredit pd Peg & $7.25 \%$ & $7.25 \%$ & $7.25 \%$ & $7.25 \%$ \\
\hline
\end{tabular}

Diagram 4.1. Persentase kredit PT. Bank Mandiri (Persero) Tbk.

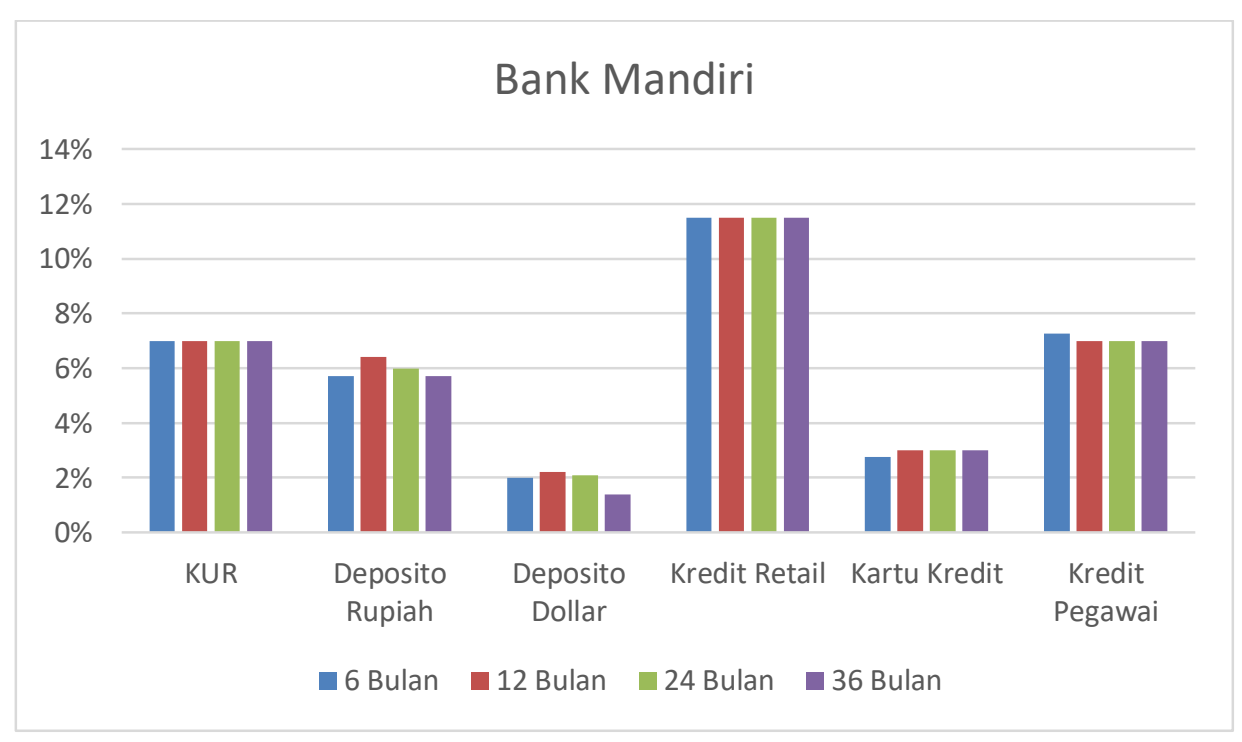

Tabel 4.5. Determinan Kredit dan Profitabilitas Nasabah PT. Bank Mandiri Determinan Kredit dan Profitabilitas Nasabah

\begin{tabular}{|l|c|c|c|c|}
\hline \multicolumn{1}{|c|}{ Jenis Produk } & 6 Bulan & 12 Bulan & 24 Bulan & 36 Bulan \\
\hline KUR & $7 \%$ & $7 \%$ & $7 \%$ & $7 \%$ \\
\hline Deposito Rupiah & $5.7 \%$ & $5.7 \%$ & $5.7 \%$ & $5.7 \%$ \\
\hline
\end{tabular}


Ekonomica Sharia: Jurnal Pemikiran dan Pengembangan Ekonomi Syariah Volume 6 Nomor 2 Edisi Februari $2021 \mid 151$

\begin{tabular}{|l|c|c|c|c|}
\hline Deposito Dollar & $1.5 \%$ & $1.5 \%$ & $1.5 \%$ & $1.5 \%$ \\
\hline Kredit Retail & $11.5 \%$ & $11.5 \%$ & $11.5 \%$ & $11.5 \%$ \\
\hline Kartu Kredit & $2,85 \%$ & $2,85 \%$ & $2,85 \%$ & $2,85 \%$ \\
\hline Kredit pd Peg & $7 \%$ & $7 \%$ & $7 \%$ & $7 \%$ \\
\hline
\end{tabular}

\section{Diagram 4.2. Persentase kredit PT. Bank Rakyat Indonesia (Persero) Tbk.}

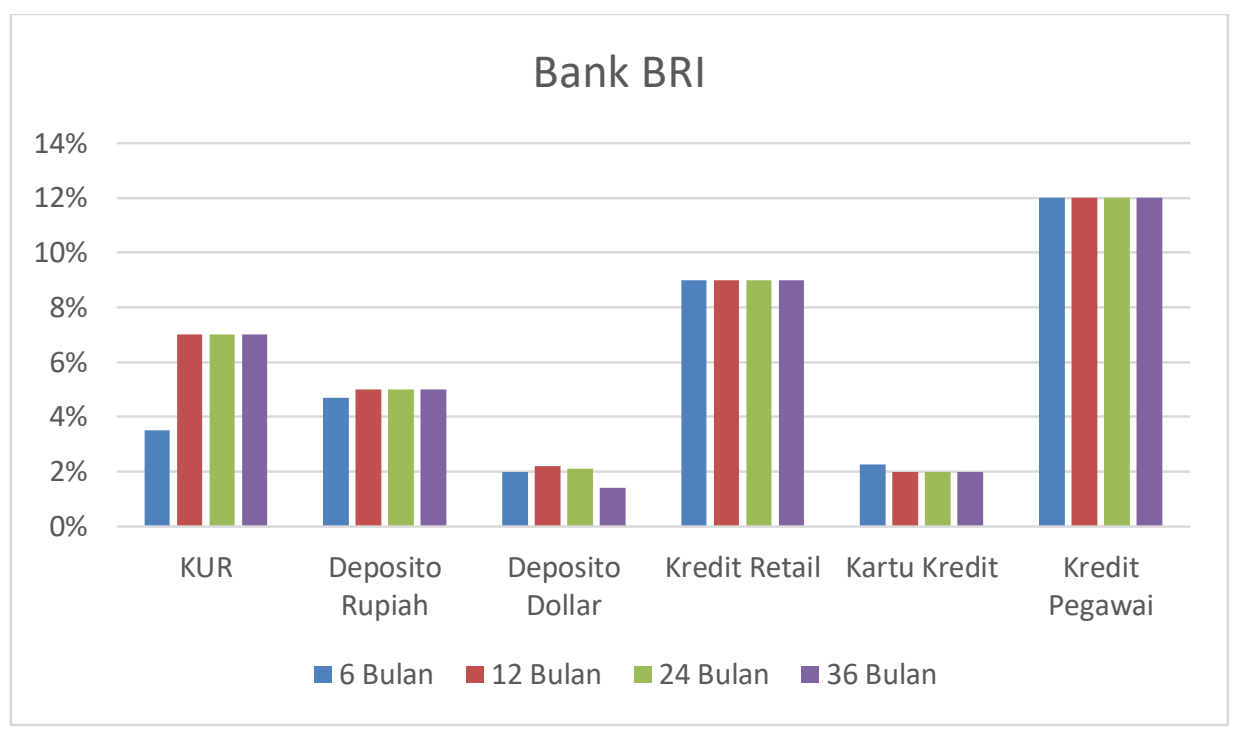

Tabel 4.7. Determinan Kredit dan Profitabilitas Nasabah PT. Bank Rakyat Indonesia (Persero) Tbk

\begin{tabular}{|l|c|c|c|c|}
\hline \multicolumn{1}{|c|}{ Jenis Produk } & 6 Bulan & 12 Bulan & 24 Bulan & 36 Bulan \\
\hline KUR & $3.5 \%$ & $7 \%$ & $7 \%$ & $7 \%$ \\
\hline Deposito Rupiah & $4.7 \%$ & $4.7 \%$ & $4.7 \%$ & $4.7 \%$ \\
\hline Deposito Dolar & $1.6 \%$ & $1.6 \%$ & $1.6 \%$ & $1.6 \%$ \\
& & & & \\
\hline Kredit Retail & $9 \%$ & $9 \%$ & $9 \%$ & $9 \%$ \\
\hline Kartu Kredit & $2.25 \%$ & $2.25 \%$ & $2.25 \%$ & $2.25 \%$ \\
\hline Kredit pd Peg & $12 \%$ & $12 \%$ & $12 \%$ & $12 \%$ \\
\hline
\end{tabular}




\section{Diagram 4.3. Persentase kredit PT. Bank BTN (Persero) Tbk.}

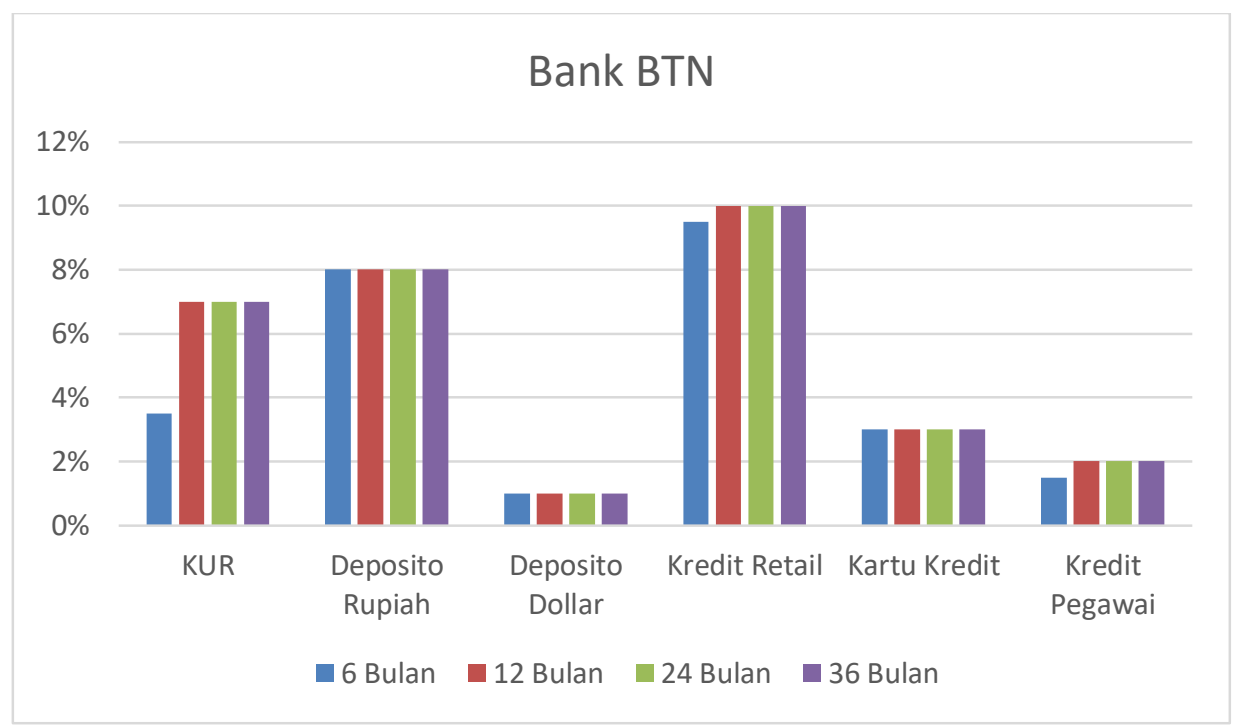

Tabel 4.8. Determinan Kredit dan Profitabilitas Nasabah PT. Bank BTN (Persero)

Tbk.

\begin{tabular}{|l|c|c|c|c|}
\hline \multicolumn{1}{|c|}{ Jenis Produk } & 6 Bulan & 12 Bulan & 24 Bulan & 36 Bulan \\
\hline KUR & $3.5 \%$ & $7 \%$ & $7 \%$ & $7 \%$ \\
\hline Deposito Rupiah & $8 \%$ & $8.3 \%$ & $8.3 \%$ & $8.3 \%$ \\
\hline Deposito Dolar & $0.8 \%$ & $0.8 \%$ & $0.8 \%$ & $0.8 \%$ \\
& & & & \\
\hline Kredit Retail & $9.50 \%$ & $9.50 \%$ & $9.50 \%$ & $9.50 \%$ \\
\hline Kartu Kredit & $2.95 \%$ & $2.95 \%$ & $2.95 \%$ & $2.95 \%$ \\
\hline Kredit pd Peg & $1.59 \%$ & $1.59 \%$ & $1.59 \%$ & $1.59 \%$ \\
\hline
\end{tabular}

Semua Tabel dan diagram diatas juga menambah bukti bahwa penyaluran kredit pada masyarakat akan sangat mempengarihi keuntungan atau tingkat profitabilitas pada Bank Umum Pemerintah.

\section{Penutup}

\subsection{Simpulan}

Berdasarkan hasil penelitian yang dilakukan dengan menggunakan sampel laporan keuangan pada Bank umum pemerintah Nasional yang terdapat di BEI Priode 20102018 dan diolah dengan Eveiws versi 9 maka dapat ditarik kesimpulan sebagai berikut: 
1) Bahwa peningkatan SIR tidak berpengaruh terhadap profitabilitas pada Bank umum pemerintah Nasional yang terdapat di BEI periode 2010-2018.

2) Bahwa kenaikan LDR berpengaruh negatif terhadap profitabilitas pada Bank umum pemerintah Nasional yang terdapat di BEI periode 2010-2018.

3) Bahwa kenaikan NPL memengaruhi terhadap peningkatan profitabilitas pada Bank umum pemerintah Nasional yang terdapat di BEI periode 2010-2018

4) Bahwa kenaikan SIR, LDR dan NPL secara bersama-sama berpengaruh terhadap peningkatan profitabilitas pada Bank umum pemerintah Nasional yang terdapat di BEI periode 2010-2018.

\subsection{Implikasi Manajerial}

Dalam rangka peningkatan profitabiltas Umum Nasional yang terdapat di BEI Priode 2010-2018 dapat dilakukan dengan menggunakan strategi peningkatan NPL terlebih dahulu yang akan berpengaruh terhadap peningkatan Profitabilitas. 


\section{DAFTAR PUSTAKA}

Aravik, H., Sulastyawati, D., \& Yunus, N. R. (2020). Leadership Concept At Sharia Bank ; 5, 21-32.

Ghozali, Imam. 2005. Analisis Multivariat dengan Program SPSS. Program Doktor Ilmu Ekonomi Universitas Diponegoro, BP UNDIP, Semarang.

Kasmir. 2012. Dasar-Dasar Perbankan. Jakarta: PT. Raja Grafindo Persada.

Pandu Mahardian (2008) melakukan penelitian yang bertujuan untuk menganalisis pengaruh Capital Adequacy Ratio (CAR), BOPO, Non Performing Loan (NPL), Net Interest Margin (NIM), dan Loan to Deposit Ratio (LDR) terhadap Return On Asset (ROA).

Syamsul, B., \& Zamzam, F. (2014). Model Penelitian Berbasis SEMAMOS, Yogyakarta: Deepubish

Tasman, Abel. dkk. 2015. Pengaruh Spread of Interest Rate Dan Kredit Bermasalah Terhadap Profitabilitas Perusahaan Perbankan Yang Terdaftar Di Bursa Efek Indonesia. Seminar Nasional Ekonomi Manajemen Dan Akuntansi (Snema) Fakultas Ekonomi Universitas Negeri Padang: Padang

Undang-Undang Republik Indonesia Nomor 10 Tahun 2008 Tentang Perbankan

Taswan. 2010. Manajemen Perbankan Konsep, Teknik, dan Aplikasi. Yogyakarta: UPP STIM YKPN.

Zulfa Majidi, 2016 menyatakan bahwa CAR, NPL, dan LDR tidak berpengaruh nyata terhadap profitabilitas pada perusahaan perbankan yang listing di BEI (20142016).

Zamzam, F. Firdaus, 2018. Aplikasi Metodologi Penelitian, Yogyakarta: Deepublish

Zamzam, F. (2015). Teknik Dasar Menulis Proposal Tesis. Palembang: NoerFikri Offset Palembang. 